Division of Geological \& Geophysical Surveys

PRELIMINARY INTERPRETIVE REPORT 2003-1

ALLUVIAL FACIES AND PALEOSOLS IN THE

CRETACEOUS NANUSHUK FORMATION, KANAYUT RIVER, NORTH SLOPE, ALASKA:

PRELIMINARY RESULTS FROM THE 2001 FIELD SEASON

by

Paul J. McCarthy

September 2003

THIS REPORT HAS NOT BEEN REVIEWED FOR

TECHNICAL CONTENT (EXCEPT AS NOTED IN TEXT) OR FOR CONFORMITY TO THE EDITORIAL STANDARDS OF DGGS.

Released by

STATE OF ALASKA

DEPARTMENT OF NATURAL RESOURCES

Division of Geological \& Geophysical Surveys

794 University Avenue, Suite 200

Fairbanks, Alaska 99709-3645

$\$ 2.00$ 



\title{
Alluvial facies and paleosols in the Cretaceous Nanushuk Formation, Kanayut River, North Slope, Alaska: preliminary results from the 2001 field season
}

\author{
Paul J. McCarthy \\ Department of Geology \& Geophysics, \\ and Geophysical Institute, \\ University of Alaska, Fairbanks, AK 99775-5780
}

\begin{abstract}
Paleosols are increasingly viewed as an important, if not critical component in nonmarine sequence stratigraphic analyses where they mark interfluve sequence boundaries and provide at least qualitative information on relative rates of accommodation change within intervening alluvial strata. However, the application of detailed paleopedological analyses to nonmarine sequence stratigraphic studies is still relatively rare.

This study focuses on alluvial and coastal plain deposits of the Cretaceous Nanushuk Formation exposed in outcrop along the Kanayut River south of the NPRA. During the 2001 field season, this site was logged and sampled for subsequent micromorphological, geochemical and mineralogical analyses. Preliminary observations indicate that pedogenic modification of alluvial deposits is common, however, rapid deposition of sediment and generally wet conditions resulted in a preponderance of weakly-developed and poorly-drained paleosols similar to modern Entisols, Inceptisols, Gleysols and Histosols. Sandstone and mudstone paleosols may contain a few large root traces, sometimes expressed as vertical to subhorizontal coalified structures or as surface cradle knolls, but they maintain evidence of primary stratification and cumulic development. Coalified and carbonaceous root traces, organic fragments, blocky structures and abundant siderite nodules provide further evidence of waterlogged conditions. By combining field observations, paleosols micromorphology, geochemistry and mineralogy with regional stratigraphic information, it is possible to pin-point the exact position of sequence boundaries in nonmarine rocks. Further work is planned in an attempt to better understand the regional distribution of paleosols in the Nanushuk Formation in order to better characterize significant nonmarine depositional hiatuses (sequence boundaries) and Cretaceous high latitude paleoenvironmental conditions.

\section{Introduction}

The purpose of this paper is to document the characteristics of Cretaceous alluvial facies and paleosols in the Nanushuk Formation (Mull et al., in prep.) exposed in outcrop in the Brooks Range foothills along the Kanayut River south of the National Petroleum Reserve - Alaska (NPRA). Increasingly, paleosols have been identified in ancient alluvial successions and used as paleoenvironmental indicators, for paleogeographic reconstructions, and as stratigraphic markers. More recently, paleosols have been shown to provide essential information for use in determining the accurate positioning of sequence boundaries in nonmarine successions, for qualitative determinations of ages of key surfaces, and for assisting in accurately identifying incised valley deposits. They also provide an additional data source for use in reconstructing basin evolution. Despite their potential, well-documented case studies of alluvial paleosols from the North Slope of Alaska are still rare, and most published
\end{abstract}


studies focus on paleosols recognized in subsurface cores rather than in outcrop where spatial and lateral relationships can be understood in more detail. This paper will contribute to the paleosol data base for the Cretaceous of northern Alaska, and forms the basis for a more extensive analysis of alluvial architecture, paleosol development and nonmarine sequence stratigraphy in this important petroleum province.

The alluvial sediments and paleosols presented here are from the upper $210 \mathrm{~m}$ of a well-exposed stratigraphic succession more than $500 \mathrm{~m}$ thick that is exposed along the Kanayut River in northeastern Alaska (Fig. 1). Macroscopic field evidence, and limited petrographic data, allows some preliminary inferences regarding past climate, relief, vegetation, parent material, and time. The potential sequence stratigraphic significance of these paleosols is discussed below. More detailed petrographic, geochemical and mineralogical analyses will be carried out in the future.

\section{Regional Geology and Stratigraphic Framework}

The Albian-Cenomanian Nanushuk Formation (Fig. 2) is a thick fluvial-deltaic and shallow marine succession that was deposited in a large east-west-trending foreland basin, widely referred to as the Colville basin. It consists of shallow marine shales at its base that coarsen up-section to fluvial conglomerates (Mull, 1985). The Nanushuk Formation is exposed discontinuously in an outcrop belt 18-30 miles wide and about 400 miles long in the northern foothills of the Brooks Range (Huffman, 1989), and is present in the subsurface throughout the northern two-thirds of the National Petroleum Reserve - Alaska (NPRA). The thickness of the Nanushuk Formation ranges from a zero depositional edge a short distance east of NPRA to more than 8000 feet in southwestern NPRA (Houseknecht and Schenk (2001). Two major deltaic depocenters have been recognized in the Nanushuk Formation. A western depocenter, referred to as the Corwin delta, was constructed by large, mud-dominated rivers that flowed toward the east-northeast (Molenaar, 1985). An eastern depocenter, referred to as the Umiat delta, was constructed by smaller, mixed load to sand-dominated rivers that flowed north and northeast from the ancestral Brooks Range through correspondingly smaller drainage basins. These depocenters do not represent individual deltas, but are thick, areally extensive delta complexes composed of many individual deltas and delta lobes (Molenaar, 1985).

Nonmarine sediments of the Nanushuk Formation are composed largely of interbedded mudstones, siltstones and sandstones. Thick coals are also present. The entire succession is capped by locally thick conglomerates. The sandstones are litharenites, with an abundance of metasedimentary lithic fragments (Ahlbrandt, 1979; Johnsson and Sokol, 1998). LePain and Kirkham (2001) discussed the reservoir potential of several sandstone facies in the Nanushuk Formation, including fluvial channel-fill, delta front, shoreface and estuarine sand bodies. Several small oil and gas accumulations have been discovered in marginal marine and shallow marine sandstones of the Nanushuk, including Umiat field which is estimated to contain 70 million barrels of oil (Molenaar, 1982; Bird and Molenaar, 1994). The Nanushuk Formation is underlain by, and interfingers with, marine deposits of the Torok Formation, and it is overlain by marine deposits of the Seabee Formation (Fig. 2). 


\section{Sedimentary Facies and Facies Associations}

Seven facies associations are defined on the basis of lithology, facies successions, bed geometry and pedogenic features. The facies associations defined for the Nanushuk Formation contain paleosols that are subdivided into four types based on color, lithology, pedogenic features and degree of horizonation.

\section{Facies Association 1: Conglomerate (gravelly fluvial channel)}

This facies association consists of chert and quartz pebble conglomerate containing channelized lenses of medium- to fine-grained sandstone $(\mathrm{Sm})$ decimeters thick and up to several meters long (Fig. 3). Clast supported, pebble and cobble gravel with crude horizontal stratification $(\mathrm{Gh})$ is most common, although trough $(\mathrm{Gt})$ and planar-cross bedded (Gp) gravel deposits are also present. Cross-bed sets vary in size from 0.2-1 $\mathrm{m}$ thick. Conglomerate packages average $5 \mathrm{~m}$ thick, but form resistant ledges up to $60 \mathrm{~m}$ thick. The lower contact of the conglomerate is typically irregular and scoured into underlying sediments with up to $1.5 \mathrm{~m}$ of relief. The upper contact is generally abrupt. At the Kanayut River section, the conglomerate can be traced laterally for more than $3000 \mathrm{~m}$. Abundant, large, coalified debris is present as lag deposits on bedding planes. Upright tree casts are rarely observed. Paleocurrent measurements from this locality indicate an east- north-easterly paleoflow.

Interpretation

This facies assemblage is interpreted as the deposits of east-northeast-flowing, low sinuosity, braided rivers. The presence of crude parallel bedding with imbricated clasts and some planar tabular cross-beds suggests deposition on diagonal bars or as diffuse gravel sheets (Hein and Walker, 1977). Sand intercalations were deposited on gravel bar surfaces during waning flow stages. Extensive lateral exposures indicate well-preserved lateral accretion and/or downstream accreting macroforms. The lack of pedogenically modified strata in this facies association suggests that fluvial erosion and deposition occurred frequently, but the presence of rare upright tree casts indicates that some bars were stable enough to support large trees.

\section{Facies Association 2: Thick fluvial sandstone (sandy fluvial channel)}

Four variants are present in facies association 2. This facies asociation (FA 2a) is characterized by thick $(5-15 \mathrm{~m})$ medium to fine-grained sandstones with tabular layers, erosive, irregular basal contacts marked by intraformational lag conglomerate (Se), overlain by a succession of sedimentary structures beginning with large-scale trough cross-beds $(\mathrm{St})$ to ripple cross-laminations $(\mathrm{Sr})$ and rarely horizontal laminations (Sh). Some sandstones are apparently massive $(\mathrm{Sm})$ and they typically fine upwards.

Thinner (2-5 $\mathrm{m}$ thick), very fine- to fine-grained sandstones have flat to irregular basal contacts (FA 2b). The sandstones may be trough cross-bedded (St) and/or ripple cross-laminated ( $\mathrm{Sr}$ ), and either fine upwards or exhibit no discernable grain size trend.

Multistory, very-fine to coarse-grained, tabular sandstones up to $10 \mathrm{~m}$ thick with variable sedimentary structures and little vertical order are also present (FA 2c). Massive, sometimes pebbly, sandstones predominate $(\mathrm{Sm})$, although trough crossbedded (St) and, locally, ripple cross-laminated sandstones (Sr) also occur. Siderite intraclast conglomerate is locally present as a lag deposit between sandstone stories. Thin interbeds of laminated siltstone or mudstone may occur between the sandstones. 
This facies assemblage commonly fines and thins upward.

Medium to very coarse-grained, planar tabular cross-bedded (Sp) or massive $(\mathrm{Sm})$ sandstone with abundant mudstone partings (FI) are also present (FA 2d). Sandstones are sharp-based and fine upwards. Shale clasts, to a few centimeters diameter occur on foresets. Internal surfaces form lateral accretion surfaces 2-10 m in thickness. Lateral pinchouts are not observed owing to the nature of the outcrop.

Overall, this facies assemblage typically incises or grades upward into thick interbedded sandstone and mudstone units or into thick mudstones with some thin sandy interlayers. Evidence of pedogenic modification includes a few mudstone pedorelicts (reworked mudstone clasts with pedogenically reorganized internal fabric), siderite nodules in lag conglomerates (Se) and, commonly, in situ plant roots in upper sandstone beds (Sm).

\section{Interpretation}

These sandstones are interpreted as fluvial channel deposits. Thick sandstones represent point bar deposits of large, high sinuosity, mixed-load, meandering channels. Thinner sandstones indicate the coexistence of smaller, mixed-load, meandering channels, or small crevasse channels. The presence of lateral accretion surfaces indicate that fluvial channels were able to migrate laterally across their floodplains (Smith, 1997). Vertically stacked, multistorey sandstones imply deposition within a meander belt complex during periods of reduced subsidence. Alternatively, these multistory sandstones may have been deposited by low sinuosity fluvial systems. The presence of mud partings and shale clasts suggests alternating flow conditions, while the presence of intraformational siderite clasts at the base of some sandstones indicates that the channels were eroding adjacent floodplains.

The identification of mudstone pedorelicts and siderite pebbles in channel lags suggests that these streams flowed across and cut into pedogenically modified floodplains. The presence of root traces in the upper layers of some channel sandstones indicates that upper point bars were colonized by large vegetation following channel migration, or that some channel areas were ermergent during low flows and stable enough for colonization by vegetation (McCarthy et al., 1997).

\section{Facies Association 3: Sandier Upward Successions (crevasse deltas)}

This facies association consists of quasi-regularly interbedded, very fine- to finegrained, lithic sandstones and mudstones (Fig. 3). Sharp-based, sandier upward successions of very-fine to fine-grained, wave rippled sandstone beds with $\mathrm{cm}$ - to $\mathrm{dm}$ scale mudstone interbeds are present. Sandstone beds thicken upward and they may also contain plane beds and current ripple cross laminations 1-3 cm thick. Siltstone interbeds are wave rippled, laminated, and commonly contain organic fragments, leaf and bark impressions. The tops of these units are sometimes rooted with coalified tree stumps up to $30 \mathrm{~cm}$ wide. This unit ranges in thickness from 1-3 $\mathrm{m}$.

\section{Interpretation}

The most important feature of this facies association is that it always overlies lacustrine silt and mud. The sandier upward succession indicates a gradual change from a low energy to a higher energy environment suggestive of upward shallowing, possibly due to deltaic progradation into a lake. The ripple cross-laminated and wave rippled, interbedded sandstone and mudstone suggests quiet water alternating with 
both oscillatory and unidirectional flows. This probably means that sediment was introduced by unidirectional currents into standing water where sand was subsequently reworked by waves. Incision by channels suggests that the units are part of a distributary system. This facies association is interpreted to represent the deposits of a crevasse delta and/or mouthbar (Coleman, 1966; Perez-Arlucea and Smith, 1997).

\section{Facies Association 4: Tabular or lenticular sharp-based sandstone (crevasse splays)}

Sharp-based, tabular or lenticular, very fine to fine sandstones that lack vertical grain size trends occur. Individual beds contain ripple cross-lamination and trough cross-bedding, occasional wave ripples, and plane bedding. Unit thickness ranges from less than $10 \mathrm{~cm}$ to more than $2 \mathrm{~m}$ with a typical thickness of $50 \mathrm{~cm}$. Individual beds commonly contain organic fragments. The tops are commonly rooted and some units contain coalified plant fragments and root traces. Upper surfaces are sharp or they are gradational into lacustrine silts and muds or paleosols.

Interpretation

The sheet-like form and sharp base of these units combined with the presence of a variety of current-formed structures is suggestive of non-channelized flow (Bridge, 1984; Ten Brinke et al., 1998). The grain size and bedforms indicate that fluvial bedload was being transported in turbulent flow and was deposited as a blanket over floodplain deposits. The presence of channels within the tabular body is suggestive of a distributary system similar to that described by Smith and Perez-Arlucea (1994) for a crevasse splay that prograded onto the floodplain by repeated reactivation.

\section{Facies Association 5: Coarsening upward rooted, silt and sandstone (levees)}

This facies association consists of plane bedded and current-ripple crosslaminated fine sandstone commonly interbedded with siltstone and/or carbonaceous mudstone. Sandstone beds are of $\mathrm{cm}$ - to $\mathrm{dm}$-scale. Units commonly coarsen upward from siltstone to sandstone or become sandier upwards. The upper surfaces of units are commonly rooted, and they may be rooted throughout and be overlain by a thin carbonaceous layer. The base of these units can be erosional or gradational. Typical thickness ranges from $0.5-3 \mathrm{~m}$.

\section{Interpretation}

The sheet-like form of the component beds of these units, combined with the presence of a variety of current formed structures, is suggestive of non-channelized flow. The grain size and bedforms indicate that fluvial bedload and suspended load were deposited simultaneously. The presence of roots throughout this assemblage suggests that the unit aggraded episodically, permitting repeated colonization by vegetation. Thin carbonaceous interbeds suggest the presence of forest or marsh litter that was subsequently buried by flooding. These features are all consistent with those found in levee deposits described by Smith and Smith (1980) and Flores and Hanley (1984).

\section{Facies Association 6: Platy mudstone: lacustrine silt and mud}

This facies consists of laminated or platy mudstone, silty mudstone or muddy siltstone (Fig. 3). Units are commonly dark grey or brown, and may display a banded 
sequence of black, brown and orange. The top few centimeters may have symmetrical ripple cross-laminations. Some units have occasional ribs of centimeter scale, siltysandstone. Millimeter to centimeter-scale siderite nodules are commonly observed. Beds typically range in thickness from a few decimeters up to $3 \mathrm{~m}$ thick.

\section{Interpretation}

The laminated or platy siltstone and mudstone suggests deposition in a low energy environment. The dark color is due to the presence of organic matter. The presence of symmetrical wave ripples is also indicative of a standing body of water. The absence of marine fossils, and the association of this facies assemblage with paleosols, crevasse splays, deltas and coals suggests that these deposits represent small lakes on floodplains (Smith and Smith, 1980).

\section{Facies Association 7: Paleosols}

A number of macromorphological features have been used to recognize paleosols in the field including root traces, soil structures, horizons, and the absence of sedimentary structures. Details of these features are first described, and then several subfacies are distinguished on the basis of depositional environments and degree of pedogenic modification.

\section{Root traces}

In situ fossil roots and root traces are one of the best criteria for recognition of paleosols in sedimentary rock successions younger than Silurian (Retallack, 2001). Fossil root traces are common in paleosols of the Nanushuk Formation. Fine, carbonaceous root traces (2-5 mm diameter, 5-20 mm long) are most common. A second type of root trace consists of carbonate filled and cemented cavities. These traces typically occur within siderite nodules and heavily sideritized zones in outcrop, and are associated with a "punky" surface texture and dark reddish orange surface mottling. Medium and coarse root traces ( 5 to $>15 \mathrm{~mm}$ in diameter) are present but are uncommon. Generally, root traces are most abundant in the top $10-50 \mathrm{~cm}$ of the paleosols and branch downward. Root traces are commonly found in clusters within the paleosols.

\section{Soil structure}

Paleosols may appear to be fragmented, featureless or massive compared to other geological structures; however, soils develop characteristic structures of their own which progressively overwhelm pre-existing structures in the parent material (Retallack, 2001). A number of macroscopic soil structural elements are found in the Nanushuk paleosols including peds, cutans, glaebules and pedotubules.

Peds are naturally occurring aggregates of soil material separated from adjacent aggregates by cutans or natural voids (Brewer, 1976). Compaction typically destroys most of the original soil peds although some are still visible in the Nanushuk Formation paleosols. Where present, the peds are angular blocky to subangular blocky and prismatic and are 0.5 to $3.5 \mathrm{~cm}$ in diameter. In fine-grained mudstones, they are commonly accentuated by waxy-looking clay films. Paleosol horizons tend to weather in a distinctive blocky pattern, which further suggests the presence of an inherent pedogenic structural control. 
Cutans are modified surfaces of peds (Brewer, 1976). Clay films aligned along ped faces occur within the Nanushuk Formation paleosols and can be recognized by their polished and finely grooved surfaces, their waxy lustre, and their random orientation on all sides of the peds. These clay films are present within most of the better developed paleosols, although they vary from very few $(<5 \%$ thin, discontinuous clay films) to common (25-50\%), moderately thick clay films. These clay coatings are not tectonic in origin and probably formed as a result of the dispersion of clays in suspension and their translocation by water moving slowly through pores and cracks in the soil (Birkeland, 1999). Clay films form in soils in which the water table is below the surface for some part of the year (Retallack, 1988; McCarthy et al., 1998).

Glaebules are naturally occurring lumps of soil material (Brewer, 1976). The most typical kinds of glaebules are nodules, concretions, and mottles. Mottles are occasionally present in the Nanushuk Formation, although the rocks have an overall drab appearance. Where present, mottles range in color from greyish red $(5 \mathrm{R} 4 / 2)$ to moderate reddish brown (10 R 4/6) or dark yellowish orange (10 YR 6/6). Mottles typically form under a fluctuating water table regime, where conditions fluctuate between reducing and oxidizing conditions. Iron and manganese present as $\mathrm{Fe}^{2+}$ and $\mathrm{Mn}^{2+}$ is precipitated as $\mathrm{Fe}^{3+}$ and $\mathrm{Mn}^{3+}$ or $\mathrm{Mn}^{4+}$ (Birkeland, 1999). The result can be a net loss of $\mathrm{Fe}$ and $\mathrm{Mn}$, but with local enrichment of these elements in the brightly colored mottles. The position and density of mottles helps indicate the position of the water table (Simonson and Boersma, 1972; McCarthy et al., 1998; McCarthy and Plint, 1998).

'Pedotubule' is a convenient nongenetic term for all tubular features such as burrows and root traces in soils and paleosols (Brewer, 1976). Root traces have been discussed above. Clearly recognizable burrows are uncommon in the Nanushuk paleosols; however, some tubular, horizontal and subhorizontal branching structures 2$5 \mathrm{~mm}$ in diameter may be burrows (cf. Sigleo and Reinhardt, 1988; Retallack, 2001).

\section{Soil Horizons}

Boundaries between soil horizons and the underlying parent material are commonly gradational. In the Nanushuk Formation, the transition from one horizon to the next commonly occurs over an interval of $2-15 \mathrm{~cm}$ (clear to gradual boundaries), and the horizon boundaries are smooth to wavy laterally. In the Nanushuk Formation, the gradual passage from one horizon to the next may reflect the upward growth of the paleosol as small amounts of alluvium were deposited on the existing soil to form cumulative profiles (cf. Kraus, 1999). Typical horizon thicknesses range from 10-60 cm.

Organic matter is present within the Nanushuk Formation paleosols as comminuted carbonaceous debris, as macroscopic fossil plant remains, and as discrete coal seams up to $5 \mathrm{~m}$ thick. The presence of preserved coals, organic matter and the overall drab color of the paleosol horizons suggests that the paleosols were waterlogged for significant periods of time.

\section{Absence of sedimentary structures}

Primary sedimentary structures are generally absent from the thicker and better developed paleosols. Destruction of original sedimentary structures is attributed to bioturbation by roots, organisms and other soil processes, such as shrinking and 
swelling (Retallack, 2001; McCarthy et al., 1998). In a few of the less well developed paleosols, there is a decrease in the amount of pedogenic alteration with depth, until original sedimentary structures, commonly parallel lamination and ripple crosslamination, become apparent in the parent material.

\section{FA 7a: rooted sandstones (incipient soils)}

Thin, tabular sandstones may contain a few, large root traces, sometimes preserved as vertical to subhorizontal, coalified structures or expressed as surface cradle knolls, but the sandstones maintain evidence of primary sedimentary stratification. Alternatively, thin sandstones may be overlain by coals less than $40 \mathrm{~cm}$ thick and/or thin, grey mudstones (less than $50 \mathrm{~cm}$ thick) with weakly developed blocky structure. The mudstones commonly contain few, dark carbonaceous or coalified root traces and a few, small orange mottles.

Interpretation

The preservation of primary sedimentary structures and the absence of pedogenic features, apart from root traces and cradle knolls, suggests incipient soil development in a sedimentologically active environment (McCarthy et al., 1997). Cradle knolls form as a result of tree-throw during windstorms. As the roots decompose, soil drops to form a mound adjacent to a pit from which the soil and root mass were extracted (Buol et al., 1989).

\section{FA 7b: coal (organic soil)}

This subfacies is black with a texture ranging from papery fissile to friable structure. Units may contain detrital fragments of leaves, twigs, bark, and fine-grained organic matter. Some thin coal units contain a high percentage of clastic material resulting in low grade coal or coaly shale. Thicker coals contain less clastic material, although many contain iron oxides. Coals range in thickness from $10 \mathrm{~s}$ of $\mathrm{cm}$ to several meters thick.

\section{Interpretation}

The high organic content, papery structure and black color are indicative of organic soils or Histosols (Leckie et al., 1989; McCarthy et al., 1999). Coal is indicative of a wet or waterlogged environment of low clastic input where the accumulation rate of organic matter is equal to the rate of subsidence. The generally low clastic contents of thick coals suggests that peat, swamp or marsh environments in this area were isolated from floodplain sedimentation for long periods of time.

\section{FA 7c: pale grey, sideritic mudstone (poorly-drained soil)}

This facies is massive to nodular, pale grey to orange-grey, silty mudstone to very-fine sandstone containing centimeter-scale carbonaceous roots, plant debris, structureless, $\mathrm{cm}-\mathrm{dm}$-scale siderite nodules, and tabular siderite concretions and layers containing root traces, and cradle knolls. Well developed bedding is absent owing to the proliferation of siderite nodules. Many siderite nodules contain root traces and plant fragments internally. These paleosols are developed in low lying areas on floodplains, or toward the tops of lake-fill successions.

Interpretation

The pale grey to grey coloring, siderite nodules and plant debris are indicative of 
a reducing, organic-rich environment (Retallack, 2001; McCarthy et al., 1999). Organic matter accumulates under anaerobic conditions which prevent decomposition. The weak structure, mottling and presence of large roots are indicative of pedogenesis in a poorly-drained or hydromorphic environment. The hydromorphic conditions are probably related to the presence of a locally high water table.

\section{FA 7d: Dark grey to brownish-grey, blocky mudstone (partially-drained soil)}

This subfacies is weakly blocky to blocky, medium to dark grey or brownish-grey mudstone and muddy siltstone with few, fine orange and reddish brown mottles. Beds contain millimeter to centimeter scale root traces and occasional siderite nodules. Sphaerosiderite is occasionally observed, most commonly in association with root traces. Waxy clay coatings are occasionally observed along ped surfaces. These paleosols typically develop in upward-fining floodplain successions, or within thick floodplain pedocomplexes (Kraus, 1999).

\section{Interpretation}

The blocky texture and presence of root traces and oxidation of siderite in this facies are indicative of pedogenic processes above the water table. For example, shrinking and swelling of fine-grained particles in response to wetting and drying of soils results in development of blocky structures (Retallack, 2001). The presence of waxy ped coatings indicates some weak illuviation of clay has occurred. This process requires the soil to wet sufficiently so that colloidal clay is physically washed down through the soil in suspension, but the soil must also dry out enough so that the clays are retained on ped surfaces (McCarthy et al., 1998). The presence of orange mottles, however, suggests iron migration under variable to poorly-drained conditions, and the presence of sphaerosiderite and grey-brown colors indicate conditions that prevented decomposition of organic matter (McCarthy et al., 1999). These features are best explained by pedogenic development in an area where water table fluctuations were a frequent occurrence. Variable drainage conditions and the weak development of peds are consistent with alternating redox conditions in a partially-drained soil (Besley and Fielding, 1989).

\section{Discussion}

\section{Paleoenvironmental interpretation of Nanushuk paleosols}

Soils form as a result of the interaction of a complex suite of soil-forming factors, including parent material, climate, organisms, topography, and time (Retallack, 2001). Some inferences on the relative influence of these factors are possible, but because a detailed understanding of vertical and lateral paleosol variability in the Nanushuk Formation is not yet available, these interpretations should be considered preliminary.

The original parent material for these paleosols is floodplain alluvium that was derived from the Brooks Range to the southwest. All of the paleosols show indications of poorly-drained conditions, at least for part of the time. Some of the paleosols have features that indicate water table fluctuations that may be attributed to topographic variations on low-lying floodplains.

The general paucity of reddish or orange colors, and the absence of caliche indicates that the climate was probably at least subhumid, although the presence of clay cutans in some of the better-developed mudstone paleosols suggests that the area was 
seasonally dry. Parrish and Spicer (1988) and Parrish and Lamberson (1998) have documented clastic successions in the Nanushuk Formation that contain abundant plant macrofossils. These macrofloral data are consistent with deciduous forests growing at a mean annual temperature of no more than $13^{\circ} \mathrm{C}$. Based on this paleobotanical data, and consideration of the paleopedological data documented here, the Nanushuk Formation probably developed under a cool temperate paleoclimate with some seasonal dryness. Spicer and Parrish (1990) also suggested that short duration frost may have been a frequent occurrence in the Nanushuk Formation, but that a long, continuous winter freeze was unlikely in these Cretaceous high latitude $\left(\sim 85^{\circ} \mathrm{N}\right)$ environments. In support of this contention, no evidence of freeze-thaw conditions has been found in paleosols from the Nanushuk Formation to date.

Most of the paleopedological characteristics observed in the Nanushuk Formation at the Kanayut River section suggest that the paleosols represent relatively short intervals of time. Most paleosols appear to have developed syndepositionally, growing upward through thin deposits of floodplain alluvium. Pedogenic processes were also probably slowed down somewhat by the relatively poorly-drained conditions present on the floodplains. A thick mudstone paleosol containing clay coatings (Fig. 3, $33 \mathrm{~m}$ ), and a thick sideritized paleosol (Fig. 3,56 m), however, may represent substantially longer periods of time than other floodplain paleosols in the section. Estimating the relative amounts of time represented by paleosols is difficult, particularly in floodplain settings where soils formed on previously weathered alluvium are subjected to cumulative processes in which soil development and sediment influxes occurred concurrently (Duchaufour, 1982). Nevertheless, these two thick paleosols may represent at least several thousands of years of soil development, which is significantly more time than is represented by other paleosols at this site.

\section{Paleosols and nonmarine sequence stratigraphy}

The original sequence model (Posamentier et al., 1988; Posamentier and Vail, 1988) predicts that cyclical changes in accommodation should also generate systems tracts on the coastal plain. The first comprehensive attempt to correlate marine with nonmarine systems tracts was presented by Shanley and McCabe (1991) whose work was particularly significant because excellent exposure permitted them to physically observe lateral transitions from marine to nonmarine deposits. Highstand time was interpreted by Shanley and McCabe $(1993,1994)$ to be characterized by continued rapid generation of accommodation as the fluvial equilibrium profile moved rapidly basinward. However, Wright and Marriott (1993) and Aitken and Flint (1995) considered the HST to be characterized by a progressively diminishing accommodation rate, reflected in progressive channel amalgamation and better developed paleosols, and culminating in complete sediment bypass as relative sea level began to fall. In Wright and Marriott's (1993) model, the degree of pedogenic maturity and soil drainage of coastal plain paleosols varies at different times in the relative sea level cycle. Their model suggests that, during sea level lowstands, mature and well-drained soils should form on terraces produced by channel incision. When sea level first begins to rise, hydromorphic soils develop because base-level is rising. As sea level continues to rise, accommodation space is created and floodplain sedimentation is rapid, leading to weakly developed paleosols. Later, during early highstand, the rate of aggradation 
begins to decrease and more strongly developed soils should form. Finally, when highstand is fully achieved, accommodation space is low and mature soils form, although their preservation potential may be low because aggradation rates are low and sediment reworking by channel combing is intense.

Sequence stratigraphic studies generally stress the importance of paleosols for identifying interfluve sequence boundaries and for distinguishing incised valley fills from major channel sandstones. In most studies, these sequence boundaries are identified by abrupt basinward facies shifts, and at the bases of incised valleys and adjacent interfluve paleosols that were largely recognized on the basis of their stratigraphic context and limited analysis of field characteristics (e.g. Aitken and Flint, 1996). McCarthy and Plint (1998) were among the first to suggest that detailed studies of interfluve paleosols, particularly focused on micromorphological data, could be used to convincingly identify sequence boundaries within thick successions of nonmarine rocks on the basis of field sedimentology, regional stratigraphy and the paleopedological characteristics of the rocks themselves. McCarthy et al. (1999a) also demonstrated that changing rates of accommodation could be qualitatively identified in floodplain and coastal plain deposits by detailed analysis of floodplain pedocomplexes. This allowed them (McCarthy et al., 1999b) to partition fine-grained nonmarine rocks into high and low acommodation systems tracts, bounded by unconformities and maximum flooding intervals. Plint et al. (2001) were ultimately able to correlate high and low accommodation systems tracts derived from sedimentological and paleopedological attributes in nonmarine rocks with highstand, lowstand and transgressive systems tracts defined in coeval shallow marine rocks. McCarthy (2002) demonstrated how detailed paleosol analyses could also be used to interpret the genesis of interfluve paleosols and unravel pedogenic pathways that varied depending upon the nature and timing of aggradation, erosion and watertable fluctuations at sequence boundaries.

All of these recent studies demonstrate that considerable information concerning the nature and timing of aggradation and incision can be derived from careful studies of alluvial and coastal plain paleosols, and that paleosols can be used to accurately determine the location of sequence boundaries in nonmarine rocks. The data presented on paleosols in the Nanushuk Formation in this study is preliminary and subsequent detailed micromorphological, geochemical and mineralogical analyses may reinforce or modify present interpretations. However, paleosols present at $33 \mathrm{~m}$ and at $56 \mathrm{~m}$ in the Kanayut River section are sufficiently distinctive that they may represent signficant hiatal surfaces. Detailed characterization of these paleosols, together with regional stratigraphic correlation will be required to accurately determine whether these surfaces are, in fact, sequence boundaries, or if they simply represent locally better developed paleosols resulting from lateral variations in drainage, topography, and sediment supply.

\section{Conclusions and Future Work}

A thick nonmarine succession of the Cretaceous Nanushuk Formation exposed along the Kanayut River south of the NPRA contains alluvial deposits and paleosols that were deposited in gravelly braided fluvial channels, in sandy meandering fluvial channels and on adjacent floodplains. Lacustrine deposits, crevasse splays, crevasse deltas, levees, coal swamps and floodplain lakes have all been recognized. Pedogenic 
modification is ubiquitous within floodplain sediments. Sedimentological and paleopedological evidence suggest that floodplain environments were predominantly poorly-drained.

The paleosols appear to have formed in a cool temperate climate with some seasonal dryness. Two paleosols appear to represent significantly longer soil-forming intervals, perhaps on the order of several thousands of years. These paleosols may represent significant hiatuses (sequence boundaries). Confirmation of the sequence stratigraphic significance of these paleosols will require further detailed characterization of the paleosols using micromorphological, geochemical and mineralogical techniques. Regional stratigraphy, sedimentology and local paleosol variability will also be used to reinforce or modify the preliminary conclusions presented here to better establish the relative influence of regional vs. local factors in paleosol development.

\section{Acknowledgements}

This work was supported by contributions to DGGS from BP Alaska, Anadarko Petroleum Ltd., Chevron, Phillips Petroleum and Alberta Energy Corp. Logistical field support was provided by DGGS.

\section{References}

Aitken, J.F. and Flint, S.S., 1995. The application of high-resolution sequence stratigraphy to fluvial systems: a case study from the Upper Carboniferous Breathitt Group, eastern Kentucky, USA. Sedimentology, 42, 3-30.

Ahlbrandt, T.S., Huffman, A.C., Fox, J.E., and Pasternack, I.,1979. Depositional framework and reservoir quality studies of selected Nanushuk Group outcrops, North Slope, Alaska. In: Ahlbrandt, T.S. (ed.), Preliminary geologic, petrologic and paleontologic results of the study of Nanushuk Group rocks, North Slope, Alaska. U.S. Geological Survey Circular 794, 14-31.

Besley, B.M. and Fielding, C.R., 1989. Paleosols in Westphalian coal-bearing and redbed sequences, central and northern England. Palaeogeography, Palaeoclimatology, Palaeoecology, 70, 303-330.

Bird, K.J. and Molenaar, C,M., 1992. The North Slope foreland basin, Alaska. In: Macqueen, R.W. and Leckie, D.A. (eds.), Foreland basins and fold belts. AAPG Memoir 55, 363-393.

Birkeland, P.W.,1999. Soils and Geomorphology ( $3^{\text {rd }}$ ed.) Oxford University Press, New York, $430 \mathrm{p}$.

Brewer, R., 1976. Fabric and mineral analysis of soils. Krieger, Huntington, N.Y.

Bridge, J.S., 1984. Large scale facies sequences in alluvial overbank environments. Journal of Sedimentary Petrology, 54, 583-588. 
Buol, S.W., Hole, F.D. and McCracken, R.J., 1989. Soil Genesis and Classification. lowa State University Press, Ames, lowa, 446 p.

Coleman, J.M.,1966. Ecological changes in a massive freshwater clay sequence. Transactions - Gulf Coast Association of Geological Societies, XVI, 159-174.

Duchaufour, P.,1982. Pedology. George Allen \& Unwin, London.

Flores, R.M. and Hanley, J.H.,1984. Anastomosed and associated coal-bearing fluvial deposits: Upper Tongue River Member, Paleocene Fort Union Formation, northern Powder River Basin, Wyoming, USA. In: Rahmani, R.A. and Flores, R.M. (eds.), Sedimentology of Coal and Coal-bearing sequences, IAS, Special Publication 7, 85-103.

Hein, F.J. and Walker, R.G., 1977. Bar evolution and development of stratification in the gravelly braided Kicking Horse River, British Columbia. Canadian Journal of Earth Sciences, 74, 562-570.

Houseknecht, D.W. and Schenk, C.J., 2001. Depositional sequences and facies in the Torok Formation, National Petroleum Reserve - Alaska (NPRA). In:

Houseknecht, D.W., (ed.), NPRA Core Workshop, Petroleum Plays and Systems in the National Petroleum Reserve - Alaska. SEPM Core Workshop, 21, 179200.

Johnsson, M.S. and Sokol, N.K., 1998. Stratigraphic variation in petrographic composition of Nanushuk Group sandstones at Slope Mountain, North Slope, Alaska. In: Kelley, K.D. and Gough, L.P. (eds.), Geologic studies in Alaska by the U.S. Geological Survey, 1998. U.S. Geological Survey Professional Paper 1615, 83-100.

Kraus, M.J.,1999. Paleosols in clastic sedimentary rocks: their geologic applications. Earth Science Reviews, 47, 41-70.

Leckie, D.A., Fox, C.A. and Tarnocai, C., 1989. Multiple paleosols of the late Albian Boulder Creek Formation, British Columbia, Canada. Sedimentology, 36, 307323.

LePain, D.L. and Kirkham, R., 2001. Potential reservoir facies in the Nanushuk Formation (Albian-Cenomanian), Central North Slope, Alaska: examples from outcrop and core. In: Houseknecht, D.W. (ed.), NPRA Core Workshop, Petroleum plays and systems in the National Petroleum Reserve - Alaska, SEPM Core Workshop, 21, 19-36.

McCarthy, P.J., 2002. Micromorphology and development of interfluve paleosols: a case study from the Cenomanian Dunvegan Formation, NE British Columbia, Canada. Bulletin of Canadian Petroleum Geology, 50, 158-177. 
McCarthy, P.J. and Plint, A.G., 1998. Recognition of interfluve sequence boundaries: Integrating paleopedology and sequence stratigraphy. Geology, 26, 387-390.

McCarthy, P.J., Martini, I.P. and Leckie, D.A., 1997. Anatomy and evolution of a Lower Cretaceous alluvial plain: sedimentology and paleosols in the upper Blairmore Group, south-western Alberta, Canada. Sedimentology, 44, 197-220.

McCarthy, P.J., Martini, I.P., and Leckie, D.A., 1998. Use of micromorphology for interpretation of complex alluvial paleosols: examples from the Mill Creek Formation (Albian), southwestern Alberta, Canada. Palaeogeography, Palaeoclimatology, Palaeoecology, 143, 87-110.

McCarthy, P.J., Faccini, U.F., and Plint, A.G., 1999. Evolution of an ancient coastal plain: paleosols, interfluves and alluvial architecture in a sequence stratigraphic framework, Cenomanian Dunvegan Formation, NE British Columbia, Canada. Sedimentology, 46, 861-891.

Molenaar, C.M.,1982. Umiat field, an oil accumulation in a thrust-faulted anticline, North Slope of Alaska. In: Powers, R.B. (ed.), Geologic studies of the Cordilleran thrust belt, Denver, Rocky Mountain Association of Geologists, 537-548.

Molenaar, C.M., 1985. Subsurface correlations and depositional history of the Nanushuk Group and related strata, North Slope, Alaska. In: Huffman, A.C. (ed.), Geology of the Nanushuk Group and Related Rocks, North Slope, Alaska. U.S. Geological Survey Bulletin 1614, 37-59.

Huffman, A.C., Ahlbrandt, T.S., and Bartsch-Winkler, S., 1989. Sedimentology of the Nanushuk Group, North Slope. In: Gryc, G. (ed.), Geology and exploration of the National Petroleum Reserve in Alaska, 1974 to 1982. U.S. Geological Survey Professional Paper 1399, 281-298.

Mull, C.G., 1985. Cretaceous tectonics, depositional cycles, and the Nanushuk Group, Brooks Range and Arctic Slope, Alaska. In: Huffman, A.C. (ed.), Geology of the Nanushuk Group and Related Rocks, North Slope, Alaska. U.S. Geological Survey Bulletin 1614, 7-36.

Mull, C.G., Bird, K.J. and Houseknecht, D.W., in prep. Revised Cretaceous and Tertiary stratigraphic nomenclature in the Colville Basin foldbelt. In: Wilson, R. and Galloway, J. (eds.), Geological Studies in Alaska by the U.S. Geological Survey, 2001. U.S. Geological Survey Professional Paper

Parrish, J.T. and Spicer, R.A. 1988. Flora of the Dunvegan Formation (Cenomanian, British Columbia) and comparison with the flora of the Niakogan tongue of the Chandler Formation (Cenomanian, Alaska). Geological Society of America, Abstracts with Programs, 21, A147. 
Parrish, J.T. and Lamberson, M.N., 1998. Cretaceous (Nanushuk Group, AlbianCenomanian) wetland environments of the North Slope of Alaska. Geological Society of America, Abstracts with Programs, A-366.

Perez-Arlucea, M. and Smith, N.D., 1997. Crevasse splay and levee development following the avulsion of the Saskatchewan River (Cumberland Marshes, Canada). Abstracts: $18^{\text {th }}$ IAS Regional European Meeting of Sedimentology, Heidelberg, September 2-4, 269-270.

Plint, A.G., McCarthy, P.J. and Faccini, U.F., 2001. Nonmarine sequence stratigraphy: Updip expression of sequence boundaries and systems tracts in a high resolution framework, Cenomanian Dunvegan Formation, Alberta foreland basin. AAPG Bulletin, 85, 1967-2001.

Posamentier, H.W., Jervey, M.T. and Vail, P.R., 1988. Eustatic controls on clastic deposition I - conceptual framework. In: Wilgus, C.K., Hastings, B.S., Kendall, C.G.St.C., Posamentier, H.W., Ross, C.A. and Van Wagoner, J.C. (eds.), Sea Level Changes: an integrated approach. SEPM Special Publication 42, 109124.

Posamentier, H.W. and Vail, P.R., 1988. Eustatic controls on clastic deposition II sequence and systems tract models. In: Wilgus, C.K., Hastings, B.S., Kendall, C.G.St.C., Posamentier, H.W., Ross, C.A., and Van Wagoner, J.C. (eds.), Sea Level Changes: an integrated approach. SEPM Special Publication, 42, 125154.

Retallack, G.J.,1998. Fossil soils and completeness of the rock and fossil records. In: Donovan, S.K. and Paul, C.R.C. (eds.), The adequacy of the fossil record. Wiley, Chichester, 133-163.

Retallack, G.J., 2001. Soils of the Past: an introduction to paleopedology, $2^{\text {nd }}$ ed. Blackwell Scientific Publ., Oxford, 404 p.

Shanley, K.W. and McCabe, P.J., 1991. Predicting facies architecture through sequence stratigraphy - an example from the Kaiparowits Plateau, Utah. Geology, 19, 742-745.

Shanley, K.W. and McCabe, P.J., 1993. Alluvial architecture in a sequence stratigraphic framework: a case history from the Upper Cretaceous of southern Utah. In: Flint, S.S. and Bryant, I. (eds.), Quantitative modeling of clastic hydrocarbon reservoirs and outcrop analogues, IAS Special Publication, 15, 2155.

Shanley, K.W. and McCabe, P.J., 1994. Perspectives on the sequence stratigraphy of continental strata. AAPG Bulletin, 78, 544-568. 
Sigleo, W. and Reinhardt, J., 1988. Paleosols from some Cretaceous environments in the southeastern United States. Geological Society of America, Special Paper $216,123-142$.

Simonson, G.H. and Boersma, L., 1972. Soil morphology and water table relations I. Correlations between annual water table fluctuations and profile features. Soil Science Society of America, Proceedings, 36, 649-653.

Smith, D.G. and Smith, N.D., 1980. Sedimentation in anastomosed river systems: examples from alluvial valleys near Banff, Alberta. Journal of Sedimentary Petrology, 50, 157-164.

Smith, D.G.,1997. Meandering river point bar lithofacies models: Modern and ancient examples compared. In: Ethridge, F.G., Flores, R.M. and Harvey, M.D. (Eds.), Fluvial Sedimentology, SEPM Special Publication 39, 83-91.

Smith, N.D. and Perez-Arlucea, M., 1994. Fine-grained splay deposition in the avulsion belt of the lower Saskatchewan River, Canada. Journal of Sedimentary Research, B64, 159-168.

Spicer, R.A. and Parrish, J.T., 1990. Late Cretaceous-early Tertiary paleoclimates of northern high latitudes: a quantitative view. Journal of the Geological Society of London, 147, 329-341.

Ten Brinke, W.B.M., Schoor, M.R., Sorber, A.M., and Berendsen, H.J.A., 1998. Overbank sand deposition in relation to transport volumes during largemagnitude floods in the Dutch sand-bed Rhine River system. Earth Surface Processes and Landforms, 23, 809-824.

Wright, V.P. and Marriott, S.B., 1993. The sequence stratigraphy of fluvial depositional systems: the role of floodplain sediment storage. Sedimentary Geology, 86, 203-210. 


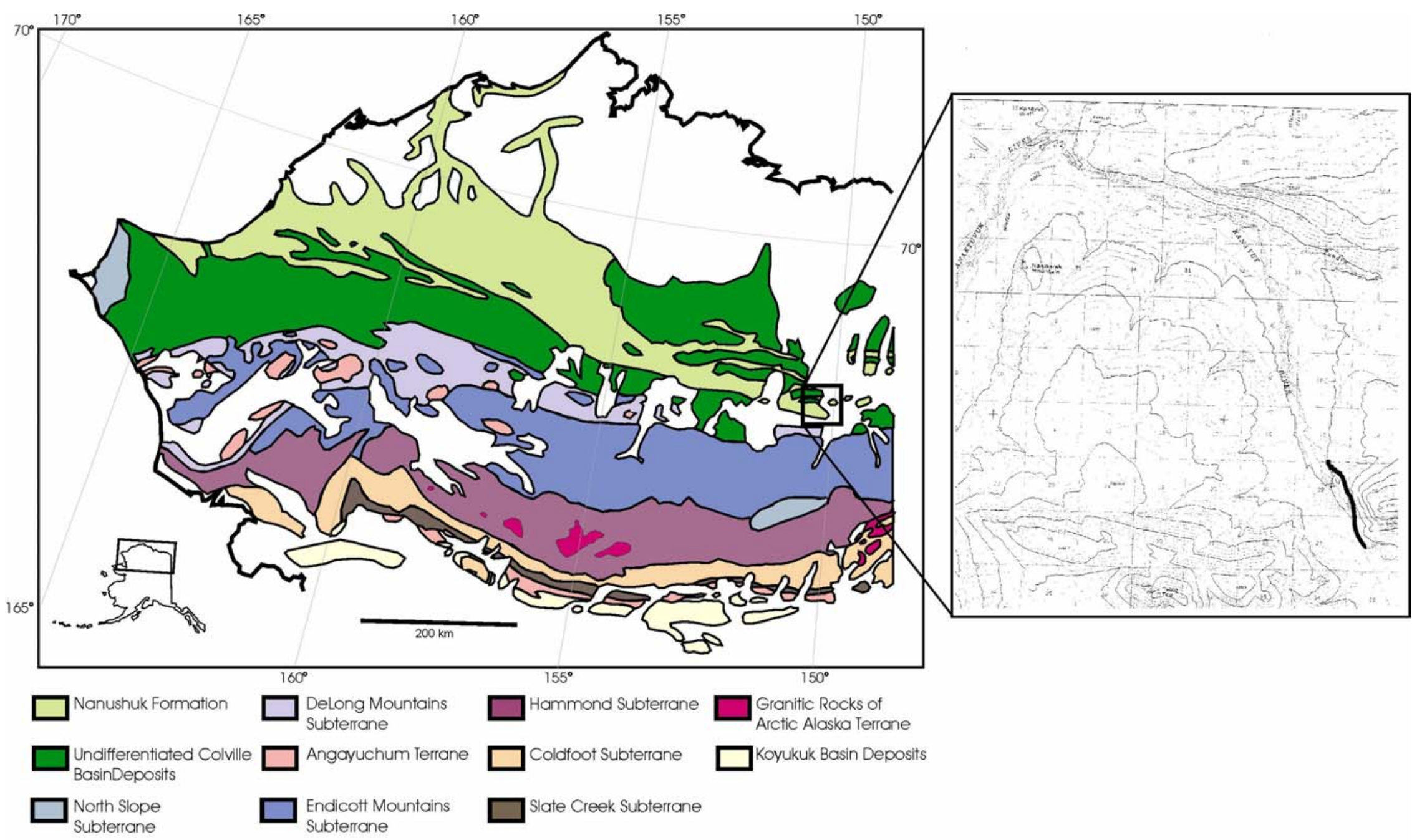

Figure 1: Geological map of the North Slope indicating the location of the Nanushuk exposure examined along the Kanayut River for this study. Location of outcrop is indicated by solid black bar on blow-up of Chandler Lake C-2 Quadrangle map to right of general geological map. The location of the base of the section $\left(68^{\circ} 39.265^{\prime} \mathrm{N}, 150^{\circ} 55.255^{\prime} \mathrm{W}\right)$ was determined by GPS without differential correction (modified from Moore et al., 1994). 
SOUTHWEST

NORTHEAST

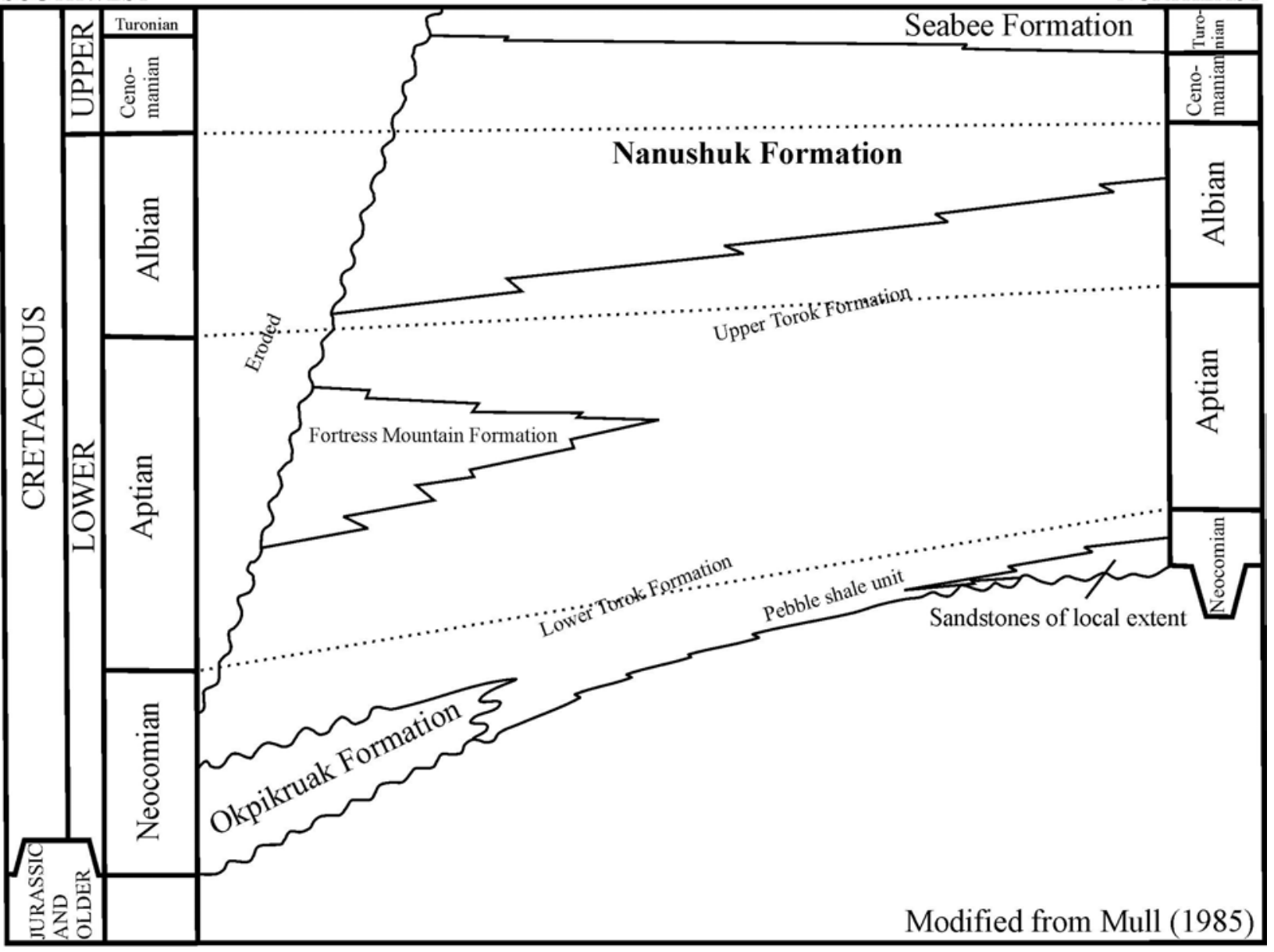

Figure 2: Generalized chronostratigraphy of Lower Cretaceous rocks in the Colville basin, northern Alaska. 

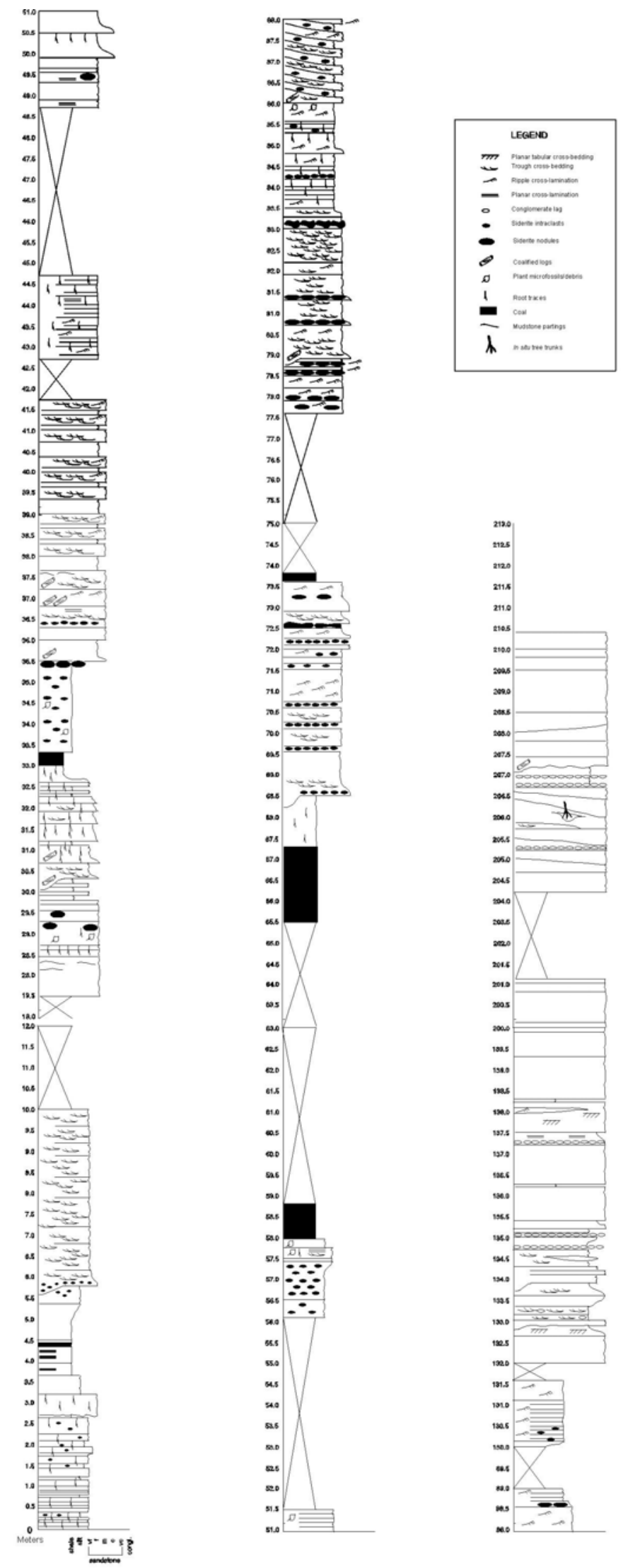

Figure 3: Alluvial deposits of the Nanushuk Formation measured at the Kanayut River section. 